\title{
Engineering Socialism: The Faculty of Engineering at the University of Dar es Salaam (Tanzania) in the 1970s and 1980s
}

\author{
Eric Burton
}

In the age of decolonization after World War II, African political leaders emphasized the need to train their own citizens as engineers in order to implement large-scale infrastructural projects, foster industrialization, and man management posts in the expanding machinery of state

Research was supported by a scholarship (Abschlussstipendium) from the University of Vienna. Research has been funded by the Austrian Science Fund (FWF) within the framework of the research project "Personal cooperation in 'development aid' and 'socialist aid' in the context of system competition" (P-25949-G16).

E. Burton $(\square)$

University of Innsbruck, Innsbruck, Austria

e-mail: eric.burton@uibk.ac.at

(C) The Author(s) 2020

D. Matasci et al. (eds.), Education and Development in Colonial and Postcolonial Africa, Global Histories of Education, https://doi.org/10.1007/978-3-030-27801-4_8 
bureaucracy and parastatal enterprises. ${ }^{1}$ More than any other field and in agreement with contemporary theories of "manpower development," investment into engineering education was seen as key to economic growth. ${ }^{2}$ As explained by the editors in the general introduction to this volume, the efforts of postcolonial governments to produce national academic elites-including engineers as well as doctors, agricultural experts, or lawyers-boiled down to two strategies: the first was to establish training institutions within the country and the second fostering training abroad, often at overseas universities. Shopping around the world for funds to implement this double strategy, these endeavors became entangled with the cultural and technical offensives of Cold War competition, the fault lines of which these governments had to navigate skilfully (on this issue, see Chapter 11 by Alexandra Piepiorka in this book). ${ }^{3}$

Tanzania was among the postcolonial states that were most successful in diversifying their aid relations following independence. By the mid-1960s, Tanzanian engineering students could be found not only in the UK and the United States, but also in the Soviet Union, Ethiopia, India, or the two German states, though the largest group was being trained in Kenya as part of an East African cooperation arrangement in the university sector. ${ }^{4}$ By that time, Tanzania was embarking on a

${ }^{1}$ Valeska Huber, "Planning Education and Manpower in the Middle East, 1950s-60s," Journal of Contemporary History 52, no. 1 (2017): 95-117.

${ }^{2}$ Osman L. El-Sayed, Juan Lucena, and Gary L. Downey, "Engineering and Engineering Education in Egypt," IEEE Technology and Society 25, no. 2 (2006): 17-24; Andrés Valderrama, Juan Camargo, Idelman Mejía, Antonio Mejía, Ernesto Lleras, and Antonio García, "Engineering Education and the Identities of Engineers in Colombia, 18871972," Technology and Culture 50, no. 4 (2009): 811-838.

${ }^{3}$ Constantin Katsakioris, "Creating a Socialist Intelligentsia: Soviet Educational Aid and Its Impact on Africa (1960-1991)," Cabiers d'Études Africaines LVII, no. 2 (2017): 259-887.

${ }^{4}$ Eric Burton, "Navigating Global Socialism: Tanzanian Students in and Beyond East Germany," Cold War History 19, no. 1 (2019): 63-83; Eric Burton, “African Manpower Development During the Global Cold War: The Case of Tanzanian Students in the Two German States," in Africa Research in Austria: Approaches and Perspectives, ed. by Andreas Exenberger and Ulrich Pallua (Innsbruck: Innsbruck University Press, 2016), 101-134. In the 1960s, the three university colleges of Kampala, Nairobi, and Dar es Salaam together constituted the University of East Africa. While regional cooperation in terms of higher education (e.g., sending of students to neighboring territories) was in some ways a continuation of British colonial policies, the postcolonial governments of Tanzania, Kenya and Uganda acknowledged in a 1967 agreement that this would only be a temporal measure. 
socialist project of development under the name of ujamaa, a variety of the African socialisms that took shape across the continent in the course of the 1960s. In contrast to African socialisms in Ghana, Kenya, Mali, Guinea, or Senegal, ujamaa had a life span of almost three decades. Formulated by the country's first prime minister and long-term president Julius Nyerere in 1962 and further shaped by him and other members of the ruling party, ujamaa was the one-party state's guiding ideology from 1967 until it was gradually dismantled in the wake of the economic crisis and structural adjustment policies of the 1980s. Important transformative policies after 1967 were the comprehensive nationalization of industries and the largest resettlement initiative in postcolonial Africa in a (largely failed) effort to create rural development villages with communal production. However, as Priya Lal has noted, ujamaa cannot be reduced to a single principle as it was contradictory both in theory and in practice. ${ }^{5}$

This was particularly visible in the educational sector where technocratic and politicized, egalitarian and elitist understandings of education coexisted. On the one hand, the state was successful in making primary education available to the whole population. This was accompanied by a drive to reeducate academics to identify with the state's development project and serve, rather than rule, the masses. On the other hand, the pyramidal system of education in which a tiny minority gained access to high-ranking positions through secondary school education and university degrees continued to exist, as did technocratic attitudes and careerism. $^{6}$

These tensions between elite-building through education and egalitarianism also informed visions and encounters at the Faculty of Engineering at the University of Dar es Salaam which was officially opened in 1973. Much against the University of Dar es Salaam's image of being a hotbed of revolutionary fervor and leftist radicalism, discussions and practices at the faculty were dominated by technocratic considerations of manpower planning and questions of economic viability.

${ }^{5}$ Priya Lal, African Socialism in Postcolonial Tanzania: Between the Village and the World (Cambridge: Cambridge University Press, 2015).

${ }^{6}$ Lene Buchert, Education in the Development of Tanzania, 1919-90 (London: James Currey, 1994), 93-122; Andreas Eckert, Herrschen und Verwalten: Afrikanische Bürokraten, staatliche Ordnung und Politik in Tanzania, 1920-1970 (München: Oldenbourg, 2007), 251-252. 
To some extent, this might not seem surprising. In Western, Eastern European, and postcolonial countries alike, the engineering profession has been closely linked to projects of modernization, industrialization, and development. Studies on different countries at different times in the twentieth century have suggested that members of the engineering profession often held technocratic attitudes (sometimes camouflaged as an "apolitical" stand) and represented a peculiar kind of "reactionary modernism" which allowed them to become thriving elites in regimes of different ideological colors. ${ }^{7}$

In the literature on state-socialist countries more specifically, engineers have been represented as being at the heart of the tension between economic and social goals. ${ }^{8}$ One of the central contradictions of socialist development strategies in the twentieth century was that they relied on elites and elite education to produce a technical intelligentsia while trying to abolish elitism at the same time. On the one hand, "experts" were needed to devise plans, to allocate resources efficiently and to administer state institutions. On the other hand, tertiary education reproduced inequalities, fueled processes of stratification, undermined efforts to level cultural, and socioeconomic hierarchies and produced a cultural elite that challenged the political elite's authority. As Joel Andreas notes for the case of Beijing's "Red Engineers" from Tsinghua University in Maoist China, students' technocratic visions and their self-image as industrializing avant-garde sharply contradicted the party's efforts to abolish class distinctions. Especially during the Cultural Revolution, but also in the following decades, Tsinghua campus represented "the epicentre of conflicts surrounding the emergence of a new class of technocratic officials." But in China, both the institution and the professional group had already existed before the revolution, while in Tanzania, the Faculty of

${ }^{7}$ Yiannis Antoniou, Michalis Assimakopoulos, and Konstantinos Chatzis, "The National Identity of Inter-war Greek Engineers: Elitism, Rationalization, Technocracy, and Reactionary Modernism," History and Technology 23, no. 3 (2007): 241-261; Dolores L. Augustine, Red Prometheus: Engineering and Dictatorship in East Germany, 1945-1990 (Cambridge, MA: MIT Press, 2007), 22.

${ }^{8}$ The classic article on the supposed dichotomy of being "Red" and being "expert" and efforts to produce a new cohort of engineers being both is Sheila Fitzpatrick, "Stalin and the Making of a New Elite," Slavic Review 38, no. 3 (1979): 377-402.

${ }^{9}$ Joel Andreas, Rise of the Red Engineers: The Cultural Revolution and the Origins of China's New Class (Stanford: Stanford University Press, 2009), vi. 
Engineering only emerged as the ujamaa experiment had already taken off and was showing its first signs of exhaustion and contradictions.

This chapter asks for the emergence and place of academic engineering education in socialist Tanzania, showing how it evolved amidst domestic and international struggles and alliances between different groups. The faculty is an excellent place to reveal the intersections of national tertiary education on the one hand with global practices of development politics and aid work on the other. The focus on a concrete arena allows us to see how donors and non-national staff shaped the agendas and practices, especially as far as the mentioned fault line between elitism and egalitarianism was concerned. ${ }^{10}$ The faculty is a concrete "arena" in which actors of different generational, national, ideological, and class backgrounds struggled over the meaning of the engineering profession and the allocation of resources. ${ }^{11}$ These struggles involved students as well as lecturers, academics, and politicians, Tanzanians and expatriates, all of whom used particular kinds of strategies to strengthen their positions and defend their interests. I argue that transnational alliances of Tanzanian and expatriate engineers, with the backing of resource-delivering donor institutions, pushed for a special status of the faculty that was at odds with ujamaa policies. As a result, the faculty spearheaded the economization at the university as part of a broader shift toward technocracy and economization. Based on archival research in Germany and Tanzania as well as oral history interviews, this contribution combines the global history of development with methods from historical anthropology to analyze global trajectories, circulating concepts, and rivalries through concrete interactions, tensions, and inequalities on the ground.

The first part of this contribution sketches the emergence of academic engineering education in Tanzania. The second part sheds light on official strategies to produce a socialist intelligentsia, while the third

\footnotetext{
${ }^{10}$ Concerning the theory of strategic groups see Hans-Dieter Evers, "Globale Macht: Zur Theorie strategischer Gruppen," Working Paper No. 322, Sociology of Development Research Centre Universität Bielefeld, Bielefeld, 1999.

${ }^{11}$ On this concept, see Thomas Bierschenk, "Development Projects as Arenas of Negotiation for Strategic Groups: A Case Study from Bénin," Sociologia Ruralis 28, nos. 2-3 (1988): 146-160; Kate Crehan and Achim von Oppen, "Understandings of 'Development': An Arena of Struggle: The Story of a Development Project in Zambia," Sociologia Ruralis 28, nos. 2-3 (1988): 113-145.
} 
part shows how nationalist and neo-Marxist critiques of the faculty coexisted with an elitist and technocratic view of the engineering profession among students. The fourth part details how faculty leadership and Western donors, seeking a response to the social effects of the economic crisis unfolding in the late 1970s and 1980s, repeatedly undermined key educational policies the government had devised to produce ujamaa-minded academics. The chapter concludes by pointing to takeaways of this case study for the global history of education and development.

\section{The International Roots of Tanzania’s National ENGINEERING EDUCATION}

The establishment of the Faculty of Engineering at the University of Dar es Salaam was the outcome of a crossing between Tanzania's aspirations of national development with the global competition for prestige in development and technology. As an institution, it was not a legacy of colonialism. The British had invested little into the educational sector of Tanganyika (which became the United Republic of Tanzania after the union with Zanzibar in 1964), a territory they had taken over from the Germans as a League of Nations mandate after World War I and continued to rule as a UN trust territory after World War II. There was no university education offered within the territory and only few secondary school graduates were available to be sent to attend university colleges at Makerere in neighboring Uganda or overseas. Among them was the country's first president and architect of ujamaa, Julius Nyerere, who ruled Tanzania until 1985. He studied first in Uganda and then, as one of the first Tanganyikans, at Edinburgh University in the UK.

Engineering education offered to Africans in Tanganyika prior to independence was of a non-academic level, which barred the graduates from entering higher positions. Two years before independence, in 1959, six students of engineering at the Principal Technical Institute in Dar es Salaam sent a letter of resignation to the Public Works Department. Despite broad popular support for the nationalist Tanganyika African National Union (TANU), it was still unclear when and how independence would be achieved. In their letter, the six students stated that they were not willing to invest any more time and efforts into an education that was of a standard much lower than that of Kampala's Engineering School in neighboring Uganda. They 
complained that the government had not only downgraded the course (from Engineering to Junior Engineering), but had also reduced starting salaries for the position its graduates were to fill. With the prestige of the certificate crumbling and career and economic opportunities further diminished, the students were not ready "to be trained in such a way that we only provide cheap labour to the Engineers," all of whom were non-Africans at the time. ${ }^{12}$

The reasons the students gave for their resignation were about career expectations which were inevitably politically and racially charged as they implicitly or explicitly challenged the racialized hierarchies of colonial rule. Governor Turnbull estimated in the same year the students had resigned, in 1959, that the territory would remain dependent for twenty years to come, as only then would there be a "sufficient number of Africans of experience, ability and integrity to fill posts in the public service, and in commerce and industry." 13 To speed up the process, TANU had pushed for higher investments into education in the late 1950s and began sourcing and allocating scholarships for training wherever it was offered, including the United States, Liberia, Ethiopia, West Germany, India, Pakistan, and other countries. ${ }^{14}$

Despite these efforts, there was only one African among 84 civil engineers in the country one year after independence in 1962 (according to other sources, there were two). ${ }^{15}$ With the economy and state apparatus projected to grow, more engineers were urgently needed for the planning, implementation, and administration of both industrial and agricultural projects. The University College of Dar es Salaam, which was established as a part of the University of East Africa eight weeks before independence with a Law Faculty in 1961, did not offer technical courses. Instead, engineering students were sent to Nairobi-an arrangement that produced the first real generation of Tanzanian engineers, but

${ }^{12}$ Chama cha Mapinduzi Party Archives (henceforth: CCMA), Dodoma, NP/003, Students of Principal Technical Institute to Director of Public Works Department, Dar es Salaam, 13 February 1959.

${ }^{13}$ Turnbull cited in Sebastian Edwards, Toxic Aid: Economic Collapse and Recovery in Tanzania (Oxford: Oxford University Press, 2014), 66.

${ }^{14}$ See, for instance, CCMA, 53-Mikutano ya Halmashauri Kuu, Memorandum of meeting of TANU Halmashauri Kuu [Executive Committee], l May 1958, p. 2.

${ }^{15} \mathrm{John}$ Iliffe, A Modern History of Tanganyika (Cambridge: Cambridge University Press, 1979), 573 . 
was soon found to be inadequate, especially as Kenya's capitalist course and Tanzania's socialist path were increasingly at loggerheads. In 1970, all three East African university colleges became national, full-fledged independent universities, a step that was widely celebrated as a major achievement and milestone in the nationalist zeitgeist of the time as expressed by Pius Msekwa, the TANU functionary Nyerere had posted to oversee the restructuring of the university as its vice-chancellor:

The establishment of a University in a country is clearly a sign of growth and maturity, and that, I know, is how the people of Tanzania view the establishment of the University of Dar es Salaam. It means that our nation has now reached a stage where it can produce its high-level manpower in circumstances and under conditions wholly decided, and guided, by the National Ethic. ${ }^{16}$

The "National Ethic" Msekwa talked about was Tanzania's brand of socialism, ujamaa. Socialism had been in the air in Tanzania since the early 1960s, but it was the 1967 Arusha Declaration that firmly put the state on a socialist path and made ujamaa the ideological basis of its development efforts. Like many other projects in Tanzania, the emergence of the Faculty of Engineering was part of a contradictory strategy of achieving self-reliance by attracting foreign aid. In 1969, Tanzania's leadership called in an international working group under the leadership of the Soviet professor S. A. Shumovsko which produced a study that recommended the establishment of a full technical faculty. A large project of this kind necessitated resources to an extent which only few countries in the world were, at the time, able and potentially willing to provide. With the Shumovsko study in hand, the government approached the Soviet Union for support but soon dropped the negotiations because the financial terms offered (loan repayment within a fairly short period of twelve years) were considered unattractive. West Germany, which was just embarking on re-establishing closer ties with Tanzania after a diplomatic crisis in the mid-1960s under the new social-democratic chancellor Willy Brandt, a friend of Nyerere, assured full financial and personal support for the project under more

${ }^{16}$ Appendix E, Vice-Chancellor's Speech for the Inauguration Ceremony 29 August 1970, in University of Dar es Salaam (henceforth: UDSM), A Report on the Activities of the University of Dar es Salaam for the Year 1970-71, Dar es Salaam 1971, p. 265. 
favorable terms. ${ }^{17}$ As the West Germany ambassador proudly reported from Dar es Salaam, Nyerere had explicitly said that the Federal Republic was his preferred donor for the engineering faculty because of its financial power and the excellent reputation of German technology. ${ }^{18}$

For West Germany, the faculty was an opportunity to gain international prestige, flex its economic muscle and export its own industrial standards and technologies to countries in the periphery. It had already, successfully if not without frictions, assisted in the establishment of technical faculties in India and Cairo. Some of the leading personnel and blueprints from these projects were then transferred to Dar es Salaam. West Germany also supported technical education on a lower level as well as the parastatal engineering company and was thus involved in the whole "pyramid" of technical education. The faculty in Tanzania became a showpiece of West German technical aid and was the most important West German project in Africa's tertiary sector. However, given the need for long-term support to make operations viable, Tanzania and West Germany agreed to approach other donors to diversify the aid structure and personal makeup of the faculty. Switzerland (from 1974 onward), Norway (1979), the Netherlands (1980), UN agencies and other donors agreed to provide support but did not effectively check West German dominance in terms of providing resources.

The university was supposed to aim at servicing "the needs of a developing socialist Tanzania," as Nyerere proclaimed in $1970 .{ }^{19}$ In practice that meant, first and foremost, the production of "manpower." Each year, the university had to train a certain number of graduates who were then to man vacant positions in parastatal companies and state bureaucracy. The engineers were to subscribe to the objectives of ujamaa. Nyerere and other politicians had felt the need to create a socialist-minded intelligentsia especially following the 1966 National Service Crisis when university students had clearly staged their elitist aspirations in a protest against compulsory government service for reduced pay after

${ }^{17}$ United Republic of Tanzania (henceforth: URT), Annual Manpower Report to the President 1969, Dar es Salaam 1970, pp. 18-19.

${ }^{18}$ BArch Koblenz, B 102/86803, FRG-Rep to Foreign Office, Dar es Salaam, 2 October 1969.

${ }^{19}$ Julius Nyerere, Inauguration Speech as Chancellor at the University of Dar es Salaam (29 August 1970), in UDSM, Report on the Activities 1970-71, 254. 
graduation. ${ }^{20}$ In 1967, Nyerere published a pamphlet on Education for self-reliance which was at odds with the economy-centered tenets of manpower planning and formed the basis of Tanzania's educational policies for the next fifteen or so years. ${ }^{21}$ The tensions between a developmentalist-cum-egalitarian ideology and pragmatic considerations gave birth to policies and practices that performed an uneasy dance between elitism, egalitarianism and the maintenance of the one-party state's authority.

\section{Socializing Engineers: Protests and Transnational TECHNOCRACY}

To understand the specificity of the faculty's role, one must first understand the opportunity structures for careers and social mobility during ujamaa. The one-party state in Tanzania radically cut opportunities for economic accumulation and initiated experiments that aimed at the leveling (or at least re-framing) of both material and cultural hierarchies. ${ }^{22}$ Not all of the state interventions into the education and careers of academics were at odds with technocratic and meritocratic principles, but some clearly were. Four measures stand out for their political relevance and the impact they had on educational and career trajectories, making Tanzania a very distinct habitat for the intelligentsia: bonding, the leadership code, the Musoma Resolution, and political education. All of these should ensure that engineers and other academics were both experts and socialists, both educated elites and servants of the masses in a spirit of egalitarianism.

The first measure was the bonding of all government-sponsored university graduates to state service. Graduates were legally required to offer their services for official institutions for five years after graduation. This procedure had been usual practice in the British colonial system, where beneficiaries of government scholarships were automatically employed by state institutions after graduation. When the postcolonial

\footnotetext{
${ }^{20}$ Andrew M. Ivaska, “Of Students, 'Nizers,' and a Struggle Over Youth: Tanzania's 1966 National Service Crisis," Africa Today 51, no. 3 (2005): 83-107.

${ }^{21}$ Buchert, Education in the Development, 93-94.

${ }^{22}$ On the East German case cf. Ingrid Miethe, Bildung und soziale Ungleichheit in der DDR: Möglichkeiten und Grenzen einer gegenprivilegierenden Bildungspolitik (Opladen: Barbara Budrich, 2007).
} 
state had secured control over most bursaries both from national and international sources, this practice was continued. For the buildup of the Faculty of Engineering in the 1970s, bonding was crucial as most engineers gravitated toward the private and parastatal industries which offered better economic prospects and career opportunities, including comprehensive fringe benefits and quicker promotion. The shortage of engineers was exacerbated by the fact the state's manpower development plans, which also determined the target "output" for university courses, only took into account the demand of state institutions. Also, in previous years, the allocation mechanism for engineering technicians (i.e., graduates of a course for sub-professional engineers) had already shown to be deficient: Those who had been recruited by government institutions often worked in administrative rather than engineering positions in line with their training; at the same time, the ministries had not enforced the bonding contract so that those who had gone to the private sector remained there. ${ }^{23}$ At university, for the sake of having more Tanzanian lecturers, the faculty enforced bonding. When some of the best graduates were headhunted by private companies in the late 1970s, they were usually required to remain at the faculty as junior teaching staff, even when they would have preferred to work for private sector companies. ${ }^{24}$

The second intervention into career trajectories was the leadership code of the Arusha Declaration, the central document of Tanzania's socialist path agreed upon by the party in 1967. Apart from charting principles of self-reliance and calling for a focus on rural rather than industrial development, the Arusha Declaration also contained a "leadership code" which applied to all higher party cadres, government officers, and civil servants. In a bid to disentangle political and economic elites and reduce leverage for material accumulation, the leadership code precluded officials_including university lecturers-from earning two or more salaries, owning shares of private businesses or renting out private property. This issue of having more than one source of income would become highly relevant at the faculty. The third intervention was the 1974 Musoma Resolution which introduced universal primary education and changed the admission criteria for higher learning, adding character

\footnotetext{
${ }^{23}$ URT, Annual Manpower Report 1969, 12-14.

${ }^{24}$ Interview \#40, Tanzanian engineer and professor.
} 
and socialist attitudes to pure merit. ${ }^{25}$ This resolution also led to tensions with donors at the faculty, as will be shown further below.

The fourth intervention was the transmission of ideology via the state's ideological apparatuses, including the media and educational institutions. At university, this became evident with the introduction of obligatory courses in development studies to students of all disciplines in 1971. The proclaimed task of the Institute of Development Studies in 1976 was "to instil into the students of this University [...] the commitment to the Ideals [sic] of the Party by giving them proper tools of analysis." 26 Despite the sound of it, classes offered were not necessarily doctrinaire, but rather oriented toward providing an overview of socialist experiences and approaches in the world. Lecturers represented a mixture of ujamaa adherents, Maoists, Western neo-Marxists as well as East Germans who fought to defend the "purity" of Marxist-Leninist teachings. All these groups pulled into different directions as far as their vision of socialism was concerned, but they shared the conviction that education needed to be inserted into a political and historical framework. Interviewees noted that as would-be engineers in the 1970s and 1980s, they generally appreciated their exposure to development studies and were proud that Tanzania had her very own national ideology and identity. ${ }^{27}$ The nationalist aspect apparently trumped the socialist elements in this appropriation of the ideology.

These measures-bonding, the leadership code, the Musoma Resolution, and political education-became enmeshed with political and ideological struggles on campus. On the one hand, the University of Dar es Salaam was a hotspot of transnational radical activism and intellectual exchange. ${ }^{28}$ At the same time, sparks of leftist mobilization were

${ }^{25}$ Cf. Julius Nyerere, The Arusha Declaration: Ten Years After (Dar es Salaam: Government Printer, 1977), 13.

${ }^{26}$ CCMA, THQ/C/E.20/7, I.D.S. Board Paper No. B/14/1975, Statement on Institute of Development Studies 1976/77 Estimates; cf. Interview with Pius Msekwa, Dar es Salaam, 23 November 2014.

${ }^{27}$ Ibrahim Kaduma, who was head of the institute and vice-chancellor of the university in the late $1970 \mathrm{~s}$, made it his task to personally teach and politicize engineering students. Interview \#40, Tanzanian engineer.

${ }^{28}$ Andrew Coulson, Tanzania: A Political Economy. Second Edition (Oxford: Oxford University Press, 2013), ix-x; Andrew M. Ivaska, "Movement Youth in a Global Sixties Hub: The Everyday Lives of Transnational Activists in Postcolonial Dar es Salaam," in Transnational Histories of Youth in the Twentieth Century, ed. by Richard I. Jobs and David M. Pomfret (Hampshire/New York: Palgrave Macmillan, 2015), 188-210. 
tramped out by authorities as soon as these crystallized into organizational forms rivaling the party or its youth wing. The autonomy of the university from the political field was significantly reduced by the political leadership. President Nyerere was the chancellor, and from 1970 to 1979 , a high-level party functionary and an ujamaa-adhering civil servant (Pius Msekwa, 1970-1977, and Ibrahim Kaduma, 1977-1979) served as vice-chancellors to oversee the nationalization of the university and adherence to party principles.

The results of this politicization in terms of attitudes were not clearcut. Despite several efforts of leftist academics as well as some party cadres to further politicize academia, the university remained an institution geared first and foremost toward producing graduates to realize the state's "manpower development plans." The first generation of Tanzanian engineers was trained overseas. The second generation of engineers was trained in Nairobi (until 1973) and the third in Dar es Salaam (after 1973), although overseas stays remained indispensable, especially for the M.Sc. and Ph.D. levels. India, China, the Soviet Union, and Eastern bloc countries such as Romania and East Germany also offered scholarships for engineering degrees, yet the vast majority of those recruited by the faculty had graduated from British and US universities-not least because those pursuing higher degrees usually opted for Western institutions. ${ }^{29}$

While the transformation of political views during overseas stays was fairly unpredictable, most Tanzanians who studied engineering were exposed to similar technocratic views geared toward plannability and industrialization. Although Tanzanian history boasted a variety of impressive techniques and technologies such as iron smelting-the famous "Dar school" historians were publishing widely on these precolonial achievements-the curriculum at the faculty remained fully centered on Western technology and standards. According to two lecturers from the university's Institute of Development Studies, engineering students that were being introduced to technological achievements

${ }^{29}$ Of 281 Tanzanians enrolled in overseas engineering courses in 1975/76, 170 were in India, 24 in China, 22 in East Germany, 16 in Cuba, 15 in Romania, 11 in Italy, 9 in Poland and 8 in Ghana. URT, Annual Manpower Report to the President 1975 (Dar es Salaam: Government Printer, 1976), 36. Note that these statistics do only include students who received their scholarship through the Ministry of National Education; also, students' courses in the USSR given as "other" very likely include many engineering students. 
from precolonial East African usually did not believe that such complex technologies had indeed existed in Tanzania. ${ }^{30}$

Engineering students also clung to a hierarchical vision in which university-trained engineers were white-collar elites overseeing blue-collar technicians. According to a 1978 study on the attitudes of engineering students, students saw the mbandisi (engineer) in sharp contrast to the fundi (mechanic, technician), charging the former vocation with "an excessively academic meaning, which in turn colours their expectations of engineering employment," freed by obligations to do manual labor. ${ }^{31}$ Nyerere personally felt it necessary to emphasize (in one of his well-known homilies addressed to professional cadres) at a meeting of the Institution of Engineers that an engineer in Tanzania needed to be ready to supervise or even execute the most basic tasks like greasing machines and turning screws himself. ${ }^{32}$ Tanzanian and expatriate staff at the faculty saw students' expectations of an exclusively managerial job as a serious "confusion of identity." 33 In the case of both technicians and engineers, their identity was coded as a male one: The first two female students at the faculty enrolled as late as 1978.

The expatriates at the faculty-who made up eighty percent of the teaching staff in the late 1970s-did not help to overcome the techno-Eurocentrism, either. The West German engineers who staffed (and, initially, led) the faculty overwhelmingly belonged to the technocratic faction and were far from embracing socialist ideals of Tanzania or any other kind. Only few had been mildly politicized in the wake of the movement of '68. One engineer, who identified as a member of that movement and who also had a degree in sociology, described himself as

\footnotetext{
${ }^{30}$ David Wield and Carol Barker, "Science, Technology and Development: Part of a Course in Development Studies for First and Second Year Engineering and Medical Students at the University of Dar es Salaam, Tanzania," Social Studies of Science 8 (1978): 385-395.

${ }^{31}$ A. S. Mawenya and S. B. Lwakamba, "The Indigenisation of Engineering Manpower Capability in Africa-Issues and Problems," 1978, cited in Bundearchiv Koblenz (henceforth: BArch Koblenz), B 213/33074, Report of an International Study Team on the FoE at the UDSM, Mai 1979, 25.

${ }^{32}$ Julius Nyerere, "The Tanzanian Engineer," Bulletin of Tanzanian Affairs, no. 21 (1985): 12.

${ }^{33}$ Mawenya and Lwakamba, "The Indigenisation," cited in BArch Koblenz, B 213/33074, Report of an International Study Team on the FoE at the UDSM, Mai 1979, 25.
} 
an "exotic" appearance at the faculty, seen as an "arrogant $[\ldots]$ knowit-all" by his conservative colleagues and unable to find support for his ideas. This even applied to relations with his students: As he tried to introduce them to participatory management styles and workers' self-management, he was cut short with the hint of a student that this would be "arts, not science." ${ }^{34}$ But actually, such progressive ideas were not foreign to Tanzania.

Tanzanian workers' struggles (including wildcat strikes and lockouts of owners and managers) to take over private and state-owned companies to introduce cooperative self-management between 1971 and 1973 had been crushed by the authorities. These initiatives had been instigated, in a somewhat absurd turn of events, by the party guidelines (Mwongozo) issued in 1971. These party guidelines had called for Tanzanians to exert control over their leaders and as such exhibited a clearly anti-elitist bend, directed particularly against the corrupt behavior, arrogance and bureaucratic authority of cultural and managerial elites. The guidelines encouraged people to speak up against "arrogant, extravagant, contemptuous and oppressive" leaders. ${ }^{35}$ Technocratic elites were stripped of their aura of authority: "It is not correct for leaders and experts to usurp the peoples' right to decide on an issue just because they have the expertise." 36 While activist students quoted the Mwongozo in a serious conflict with the university leadership in 1971 (the Akivaga Crisis), ${ }^{37}$ most of the engineering students who began studying after 1973 seem not to have taken these anti-elite demands to heart to an extent that it would have changed their ambitions. For them as for most other young Tanzanians, there were few possibilities for social mobility through economic accumulation during ujamaa, meaning that education remained the most important mechanism of upward mobility. Engineering

${ }^{34}$ Interview \#122, GTZ expert.

${ }^{35}$ Cited in Issa G. Shivji, Class Struggles in Tanzania (London: Heinemann, 1978), 121.

${ }^{36}$ Cited in P. L. Raikes, "Ujamaa and Rural Socialism," Review of African Political Economy, no. 3 (1975): 33-52, here: 38. On political vs. technocratic decision-making in Tanzania confer also Gerhard Tschannerl, "Rural Water Supply in Tanzania: Is Politics or Technique in Command?" in African Socialism in Practice: The Tanzanian Experience, ed. by Andrew Coulson (Nottingham: Spokesman, 1979), 86-105.

${ }^{37}$ Michelle E. Bourbonniere, "Debating Socialism on the Hill: The University of Dar es Salaam, 1961-1971," MA Thesis (Dalhousie University, 2007); Munene D. Njagi, "The Upheaval Against Bureaucratic Arrogance," Maji Maji, no. 3 (1971): 1-6. 
students, thus, expected a prestigious office job with good pay and remained at a distance to both zealous party functionaries and student politics. When engineering students complained or even turned to activism, this was closely related to the technocratic image of the vocation and career goals - even when the complaints were framed in politicized terms, as was the case in the mid-1970s.

\section{Engineering Education Under Conditions of Dependency}

One year after the inauguration of the faculty, in 1974, thirteen students were at the brink of being dismissed due to poor performance. Trying to avoid their expulsion, student representatives penned an open memorandum addressed to the university senate. This memorandum is one of the few instances in which the "voice" of students appears in the archive. Significantly, the students chose to couch their concerns in the language of dependency, explicitly problematizing the faculty's asymmetric relation to West Germany:

[W]e are almost totally depe[n]dent on the good will, staff, the expertise and machinery of West Germany in the creation of this important faculty. It is for this reason that this is yet another technological dependence which will tie Tanzania to the technologies and the machines of West Germany ${ }^{38}$ and which will produce Tanzanians capable of servicing imported technologies rather than of producing locally designed and locally built technologies. ${ }^{39}$

This was not the students' own words but a quote from a text by Amon J. Nsekela, then chairman of the university council. ${ }^{40}$ Dependency

\footnotetext{
${ }^{38}$ Indeed, as the technological equipment was imported from West Germany, Tanzania had to purchase the spare parts from West German companies as well. BArch Koblenz, B $213 / 33056$, Küper (GTZ), Minutes of a meeting at the Faculty of Engineering, Dar es Salaam, 29 November 1975, p. 2.

${ }^{39}$ Amon J. Nsekela (Chairman of the University Council), Communication from the Chair Council Memorandum No. 18.9, cited in BArch Koblenz, B 213/33043, An Open Memorandum to the Senate Regarding the Faculty of Engineering, 2 April 1974, p. 1.

${ }^{40}$ On Nsekela's biography, including many leading positions in state institutions, see Amon S. Nsekela, Socialism and Social Accountability in a Development Nation: Problems in the Transformation of the Tanzanian Economy and Society (Nairobi: Kenya Literature Bureau, 1978).
} 
theory had arrived at the helm of its influence in Tanzania, shaping the country's development plans and sharpening the awareness of multiple relations of inequality between "developed" and "underdeveloped" countries. In addition to Nsekela, several neo-Marxist scholars at the university including Walter Rodney, Issa Shivji, and Gerhard Tschannerl had publicly raised their concerns against West German support. They pointed to economic and political strings attached and the Federal Republic of Germany being a close NATO ally of imperial Portugal and important trading partner of apartheid South Africa-while Tanzania actively supported liberation movements like the ANC, the MPLA, and FRELIMO, many of which had their offices in Dar es Salaam and ran refugee camps and training institutions in the country. ${ }^{41}$

While not all students were ardent supporters of these liberation movements, they did react strongly against displays of racial superiority in their own field. Their aspirations and modernist visions of industrializing Tanzania clashed with the demeaning comments of some West German mechanics and lecturers, as was mentioned in the memorandum:

The attitudes expressed by some staff members of the faculty are unacceptable as regards our aspirations. Their attitudes are biased against the students' capability to perform any duty or 'create' independently. One workshop instructor told a group of students [...] that 'It is impossible for Tanzanians to manufacture complicated machines. The best we can do is to train the students such that they can maintain and repair these machines and we should prepare them for making spare parts for these machines'. The implication is that such an instructor has a belief that an African student is incapable of performing or pursuing technical jobs or procedures. ${ }^{42}$

These beliefs were not only at odds with the proclaimed technocratic objectives of the academic training- "To train engineers, who shall be able to solve Tanzania's problems," "to instil a capacity for leadership and for independent and creative activity" 43 - they were also received as

\footnotetext{
${ }^{41}$ Politisches Archiv des Auswärtigen Amtes, Berlin (PAAA), MfAA, B 279/74, GDR expert B. to GDR-Rep, Dar es Salaam, 30 August 1973.

${ }^{42}$ BArch Koblenz, B 213/33043, An Open Memorandum to the Senate Regarding the Faculty of Engineering, 2 April 1974, p. 6.

${ }^{43}$ BArch Koblenz, B 213/33043, GTZ, University of Dar es Salaam. Faculty of Engineering, Eschborn 1979, p. 14; ibid., B 213/33074, Report of an International Study Team on the FoE at the UDSM, May 1979, p. 52.
} 
racist insults. Still, Western expatriate lecturers routinely emphasized cultural differences and inadequate intellectual capacities (most commonly a supposed lack of three-dimensional thinking and analytical skills) to explain unsatisfying student performances. Some framed the difficulties they experienced in knowledge transfers in terms of civilizational difference, feeling that they had to bridge a "gap of centuries" between their habitus, shaped by the requirements of industrial society, and students' thinking from rural and traditional backgrounds that supposedly lacked concepts of measured time, machines (and the necessity to maintain them properly), or the right angle, all of which were figured as symbols of modernity alien to Tanzania. ${ }^{44}$ Even beyond conceptualizing this gap as a difference between rural and urban lifestyles, ${ }^{45}$ they often framed it as a difference between Europeans and Africans.

The memorandum was not the product of an isolated (or even radical) minority of students unfairly putting the blame for their failure on expatriate teachers. Quite the opposite, the concerns brought forward in the memorandum resonated with widespread discontent at the faculty. In 1975, several lecturers faced student boycotts, the major reason for which seem to have been insufficient language skills of expatriate staff (note that strikes were an established strategy of Tanzanian students of all political colors at secondary and tertiary level to protest against inadequate teaching or learning conditions; this is not to be confused with radicalism or activism). ${ }^{46}$ Students also aired grievances that lecturers showed no understanding for their personal problems and the socioeconomic setting of studies. As mentioned above, German lecturers saw cultural differences as the major cause of inadequate performance, blaming the students rather than themselves for failing to bridge these differences. According to the few Tanzanian lecturers that were at the faculty, however, the relevant factors that negatively affected performance were

${ }^{44}$ Interview \#122, GTZ expert; BArch Koblenz, B 213/33056, Dietrich Goldschmidt, Die Errichtung der Ingenieurfakultät an der Universität Dar-es-Salaam und Probleme ihres Curriculums, November 1975, S. 3.

${ }^{45}$ BArch Koblenz, B 213/33074, Report of an International Study Team on the FoE at the UDSM, May 1979, pp. 52,61.

${ }^{46}$ BArch Koblenz, B 213/33043, Kreuser, Projektbericht Nr. 14, Dar es Salaam, 1 November 1975; GTZ, Bildung und Wissenschaft in Entwicklungsländern. Die Maßnahmen der staatlichen deutschen Bildungs- und Wissenschaftsförderung (Eschborn: GTZ, 1975), 190. 
living conditions which were not conducive for learning, including uncertain career prospects, a lack of funds and family pressures. ${ }^{47}$ Family pressure applied particularly to those students who did not come from privileged backgrounds, students which had excelled academically and owed their rise, at least partially, to ujamaa's social policy and meritocratic mechanisms. ${ }^{48}$

Still, while there were tensions between students and faculty staff, these were not based on diverging political outlooks but rather centered around the promise of engineering education as an avenue to a better future-both for the country and individual students. Protests in which Tanzanian students or lecturers employed the rhetoric of dependency theories were short-lived and always connected to grievances about material conditions and the inability of expatriate lecturers to transmit technical knowledge, rather than educational concepts and political questions as such.

\section{EngineEring Socialism: Economization \\ AND THE UNDERMINING OF EgALITARIANISM}

The 1974 Musoma Resolution stipulated that only those secondary school leavers who had worked at least two years and were able to produce a recommendation by their employer and their local party branch could enter university. This new regulation has widely been interpreted as a means not only to transmit practical experience and the right attitude toward the working population, but also to ensure academics' loyalty, thus producing "a docile university population." 49 The Musoma Resolution's impact was quickly felt at the faculty: Instead of the 120 students expected, only 65 took up their studies in 1975.

This reduction in student numbers did not go down well with the donors. The West German Federal Ministry of Economic Cooperation argued that the under-utilization of the faculty's capacities would lead to serious problems in legitimizing the enormous costs to the German

${ }^{47}$ BArch Koblenz, B 213/33043, Hartmut Glimm (DSE), Evaluation of Participants Questionnaire No. 1, pp. A2, D2, May 1974.

${ }^{48}$ Göran Hydén, Beyond Ujamaa in Tanzania: Underdevelopment and an Uncaptured Peasantry (London: Heinemann, 1980), 161.

${ }^{49}$ Arnold Temu and Bonaventure Swai, Historians and Africanist History: A Critique (London: Zed Books, 1981), 168; cf. Coulson, Tanzania, 273-274. 
public (in total, the project would cost over 100 million Deutschmark), which in turn might lead to a reduction of funding available to the project. Representatives flexed the economic muscle and exerted pressure on the university leadership to bend national policies. They proposed that the faculty be granted an exemption to the Musoma Resolution or take in students from other African countries, financed by West German scholarships-a proposal that contradicted Tanzania's drive toward nationalization and self-reliance. In a direct conversation, the responsible minister bluntly refused any exemption to the Musoma Resolution; the university leadership also received the demands coldly and seemed "not particularly touched" by the West German concerns. ${ }^{50}$ As such, it came as a surprise to the donors that an exceptional rule was granted to the faculty shortly after. In 1976, courses were filled with young students directly entering after their graduation from secondary school. ${ }^{51} \mathrm{It}$ is very likely that many Tanzanians-including the minister and university leadership - generally sympathized with the substance of the donor demand for technocratic reasons but resented the interventionist character of the demand. Also, they had little leverage to challenge a measure that had just been introduced with Nyerere's blessings. ${ }^{52}$

In the same year, in 1976, Nairobi- and UK-trained engineer Awadhi Mawenya took over as the first Tanzanian dean of the faculty and served in this function until 1982. As Mawenya emphasized retrospectively, the faculty's concentration of "talent" (i.e., expertise) and "very sophisticated equipment," mostly from Germany, was unique in the countryand opened up commercial opportunities. Already in 1975, the Civil Engineering Consultancy Office (CIVECO, replaced by the Bureau of Industrial Cooperation, BICO, in 1990) had been established to link the faculty to practical projects. Mawenya remembered the establishment of

${ }^{50}$ BArch Koblenz, B 213/33056, Küper (GTZ), Vermerk über ein Gespräch mit dem Chief Academic Officer der UDSM Prof. Kimambo am 27.11.1975, Nairobi, 3 December 1975 , p. 4.

${ }^{51}$ BArch Koblenz, B 213/33056, Kreuser, Projektbericht Nr. 16, Dar es Salaam, 29 April 1976. Another exemption was made for women, whose share of new entrants had sunken as a result of the Musoma Resolution. The women's wing of the party had been instrumental in pushing for this exception. Buluda Itandala, "University of Dar es Salaam's Immediate Response to Musoma Resolution," in In Search of Relevance: A History of the University of Dar es Salaam, ed. by Isaria N. Kimambo, Bertram B. Mapunda, and Yusufu Q. Lawi, 193-205 (Dar es Salaam: Dar es Salaam University Press, 2008), 200.

${ }^{52}$ Cf. Nyerere, The Arusha Declaration: Ten Years After, 13. 
these links to the industry in terms of personal advancement rather than in terms of usefulness for the faculty or the country's development at large:

We did many things which could help staff members to progress. [...] Of course you faced a lot of problems with the university administration because the very concept of getting a second income was not allowed [...]. I personally spent a lot of time with the vice chancellor to explain. I said, "We are engineers. You should treat us like medical people. You cannot say you are a teaching engineer when you don't practice engineering. Just like a doctor. You cannot teach doctors when you don't have patients." 53

The reference to doctors was not coincidental: similar to engineers at the university, doctors responded to decreasing real income with the demand for the right to practice privately in 1981. Similar to engineers, doctors began leaving the country in the late 1970s and early 1980s. Private practice was partially legalized but also repeatedly attacked as driver of "crypto-capitalist" developments. ${ }^{54}$ Resistance against similar changes for professionals at the Faculty of Engineering also came on ideological grounds. A West German lecturer who described himself as a central figure in the establishment of consultancy services at the faculty remembered that he was summoned by the university leadership and accused of "introducing capitalist practices." ${ }^{55} \mathrm{He}$ emphasized that these worries were not present at the faculty itself. The argument at hand was that the economic opportunities provided would also ensure that staff remained at the faculty. Another committee at the faculty, made up only of Tanzanians, had voiced demands for additional incentives including higher salaries, more opportunities for advancement and bonus payments for those who incremented the faculty's income through consulting services. ${ }^{56}$

As the struggle for more incentives continued, three of the still few Tanzanian lecturers (there had only been eight in 1978) quit right after

${ }^{53}$ Interview with Awadhi Mawenya, Dar es Salaam, 7 October 2014.

${ }^{54}$ John Iliffe, East African Doctors: A History of the Modern Profession (Cambridge/New York: Cambridge University Press, 1998), 208.

${ }^{55}$ Interview \#105, West German lecturer (local contract with top-ups).

${ }^{56}$ BArch Koblenz, B 213/33077, Ad Hoc Committee Report on Measures to Address Dissatisfaction of Tanzania Staff, 23 August 1979. 
their three-year bonding period had ended and went to work for parastatal or private companies. ${ }^{57}$ The "Tanzanization" of the faculty seemed to become an open-ended project. A team of eighteen evaluators (including both Tanzanians and expatriates from various countries) recommended to tackle the situation of competition with the economic sector head-on, recognizing that the suggested measures to improve the staff situation "might create problems of equity for the University," but were "probably unavoidable $[. .$.$] in a market situation in which individ-$ ual employment choices beyond the bonding period are respected." 58

The proposed measures included-still recognizing that a second income was precluded by the leadership code-the provision of funds for international conference visits, an allocation of resources for membership fees in professional associations and scientific literature as well as a new loan scheme (in addition to already existing schemes for motorbikes and fridges) that should allow Tanzanian staff to build their own houses, taking into account the housing crisis on campus. The representative of the West German aid agency GTZ (Gesellschaft für Technische Zusammenarbeit) also demanded, in 1979, further measures to stop the exodus. ${ }^{59}$ He was backed by the West German government which shortly thereafter included a clause in an aid agreement that the faculty "shall undertake special efforts to ensure that the Tanzanian academic and non-academic staff at the Faculty of Engineering remain employed there in line with demand." 60 With pressure from the faculty's most important donor, initiatives from Tanzanian staff also stood a better chance of success.

Eventually, Mawenya got a Swiss lecturer to write a proposal that was subsequently approved by the university's senate and council. As a result, engineers were now practically exempted from the leadership code: "We were then able to do what other people what call private work at university, but we didn't see it systematically as private work, it was official, because

${ }^{57}$ BArch Koblenz, B 213/33077, Hartmann (GTZ/FoE) to Füllenbach (GTZ), Dar es Salaam, 10 October 1979. In 1978, there had been 69 academic posts, only 8 of which were filled by Tanzanians, 44 by expatriates, and 17 vacancies.

${ }^{58}$ BArch Koblenz, B 213/33074, Report of an International Study Team on the FoE at the UDSM, May 1979, p. 100.

${ }^{59}$ BArch Koblenz, B 213/33077, Küper and Füllenbach (GTZ) to Mawenya (Dean of the Faculty of Engineering), Eschborn, 1 October 1979.

${ }^{60}$ BArch Koblenz, B 213/33088, Entwurf zum Regierungsabkommen, no date, p. 6. 
the income was divided into three portions" (thirty percent for individuals, thirty percent for the faculty, forty percent for the facilities that were being used). ${ }^{61}$

It is important to point out here that extra income did by no means automatically mean economic accumulation. Beginning with the mid1970s and until the late 1980s, real income from regular salaries was melting away. As inflation spiraled further, fringe benefits offered in the parastatal and private sector outcompeted whatever the faculty had to offer; even Mawenya left in 1984 as the official salary did not suffice to make ends meet. As the government was forced (due to budget constraints and structural adjustment programs) to further cut down university funding, donor resources and fringe benefits remained crucial to keep the operations of the faculty going. The monthly salary hardly lasted for a week and extra activities were indispensable to eke out a living. Donor representatives estimated in 1989 that the unofficial consulting services of Tanzanian staff amounted to five to ten times of what they offered through the faculty's institutions. ${ }^{62}$ Consequently, teaching in these years was mostly done by those who received top-ups or expatriate salaries, while Tanzanians' side activities were tolerated.

More quickly than any other group at the university, engineers forged close contacts with the economic sector and were trailblazers of both legitimate and illicit paths to convert their knowledge into financial gains. With their networks ${ }^{63}$ and professional associations (which guarded the symbolic capital of university graduates against engineers without academic training), they were well-prepared for the post-socialist era and the neoliberalization of the university and the economic sector.

\section{Conclusion: The Legacies and Inequalities of Technocraticizing Socialism}

Despite many problems encountered, the establishment of the faculty has been widely regarded as a success. Until 1990, 1300 students had graduated with a B.Sc. and 21 students had finalized the newly introduced

${ }^{61}$ Interview with Awadhi Mawenya, Dar es Salaam, 7 October 2014.

${ }^{62} \mathrm{BMZ}$, B 213/48207, Bericht über Besprechung zum Thema Ingenieurfakultät und IPI, Bonn, 30 March 1989.

${ }^{63}$ Cf. for the 1990s: Tom Hewitt and David Wield, "Tanzanian Networks: Networks in Tanzanian Industrialisation," Science and Public Policy 24, no. 6 (1997): 395-404. 
Master of Science curriculum. Academic engineering education in Dar es Salaam as well as abroad led to the emergence of a new professional group that has ever since claimed a special role in the country's development aspirations. The concrete shape of engineering education was not uncontested, however. In the 1970s and 1980s, the faculty was an arena of struggles in which diverse groups-including students, Tanzanian and expatriate lecturers, donor organizations and the university leadershiptook part.

Academic engineers had a particular interest in reforming Tanzanian socialism: more often than other professional groups, they switched between academia and consultancy work and thus had two paid jobs rather than the one allowed by the leadership code. They advocated for salaries larger than that of their colleagues at university and profitted from straddling the line between university and the economic sector. An outcome of these struggles was that the faculty received a special status that contradicted national policies. To be sure, official policies were undermined through a number of groups as the economic crisis intensified and forced people to eke out a living with all kinds of strategies. The particularity of the faculty is that here, this could be done formally, while the leadership code itself was not renounced until 1991 with the Zanzibar Declaration. ${ }^{64}$

As this chapter has shown, this was not a natural process. The slight changes eventually leading to larger transformations were the outcome of struggles by an alliance of national and expatriate staff of the faculty with the university leadership. Only thanks to this alliance were engineers capable to change the rules. More generally, international cooperation in educational development has significantly contributed to the universalization and globalization of Western standards and attitudes-definitely so in the realm of engineering. Many of the policy changes were reactions to historically particular problems rather than long-term strategies guided by ujamaa principles. The economization at the faculty was a result of the economic-cum-social crisis that gathered momentum shortly after the establishment of the faculty. Given the political as well as economic constraints, Tanzanian as well as German actors saw few other

\footnotetext{
${ }^{64}$ The accompanying statement of the National Executive Committee of the ruling party CCM (the successor to TANU) even encouraged party leaders to engage in trade in production, signaling a clear ideological shift in the party leadership. Aili M. Tripp, Changing the Rules: The Politics of Liberalization and the Urban Informal Economy in Tanzania (Berkeley: University of California Press, 1997), 187-188.
} 
options than pushing for more economic incentives to curb the exodus of Tanzanian faculty staff.

Transnational linkages, including overseas education, the recruitment of expatriate personnel and donor relations gave these struggles over the education and careers of engineers a character that clearly transcended the national. The economic crisis was a catalyst for introducing material incentives in an official institution even before Tanzania was openly pressured by the IMF (after 1979) and other donors (all of which joined the IMF's rallying cry for conditionality until 1985) to implement structural adjustment policies. The academic engineers succeeded in turning their specific cultural and symbolic capital into the basis for economic opportunities, a strategy of appropriation that was necessary to mitigate the brain drain from the faculty to parastatals in Tanzania and private companies abroad. Better working conditions in the economic sector legitimized changes at the faculty; in many ways, procedures and incentives at the faculty were economized.

In a long-term view, the Faculty of Engineering helped to uphold the status and privileges of academically trained engineers from colonial to socialist and post-socialist times. But the legacy of the asymmetric global relations under which the engineering profession in Tanzania emerged still shapes careers and engineering education. Although, according to official figures, the country meanwhile boasts over 30,000 engineers, compared to one or two at the eve of political independence, ${ }^{65}$ aid and investment contracts continue to stipulate that expatriate engineers be employed to lead and implement larger projects, even in fields in which local expertise is available. ${ }^{66}$ The complaints echo the grievances of the six engineering students who objected in 1959 to the fact that they were being trained to serve as aides. The hierarchies that became reinstated through donor policies in the 1980s mirrored the racialized pattern established during the colonial era: West Germany paid top-ups for expatriates on a private contract basis (i.e., not in the framework of bilateral cooperation), many of whom originated from India. Top-ups for Tanzanians were not paid

${ }^{65}$ URT, National Five Year Development Plan 2016/17-2020/21, 30 March 2016, p. i, http://www.mof.go.tz/mofdocs/msemaji/Five\%202016_17_2020_21.pdf.

${ }^{66}$ According to John Masuha, chair of the Engineering Registration Board, around 200 Tanzanian engineers failed to be employed in 1999 because the vacancies were filled with "unqualified" expatriates. Ronald Aminzade, Race, Nation, and Citizenship in Post-colonial Africa: The Case of Tanzania (Cambridge: Cambridge University Press, 2013), 306. 
(only Switzerland would later do so to reduce informal activities and ensure staff presence at the faculty) with the argument that this would be detrimental to achieving the goal of sustainability. ${ }^{67}$ The engineering profession with its transnational networks and ethos remained marked by power differences and larger structures of dependency which go back to the colonial era and could not be overcome by technocratic education alone.

\section{BiBLIOGRAPHY}

Aminzade, Ronald. Race, Nation, and Citizenship in Post-colonial Africa: The Case of Tanzania. Cambridge: Cambridge University Press, 2013.

Andreas, Joel. Rise of the Red Engineers: The Cultural Revolution and the Origins of China's New Class. Stanford: Stanford University Press, 2009.

Antoniou, Yiannis, Michalis Assimakopoulos, and Konstantinos Chatzis. "The National Identity of Inter-war Greek Engineers: Elitism, Rationalization, Technocracy, and Reactionary Modernism." History and Technology 23, no. 3 (2007): 241-261.

Augustine, Dolores L. Red Prometheus: Engineering and Dictatorship in East Germany, 1945-1990. Cambridge, MA: MIT Press, 2007.

Bierschenk, Thomas. "Development Projects as Arenas of Negotiation for Strategic Groups: A Case Study from Bénin.” Sociologia Ruralis 28, nos. 2-3 (1988): 146-160.

Bourbonniere, Michelle E. "Debating Socialism on the Hill: The University of Dar es Salaam, 1961-1971.” MA Thesis, Dalhousie University, 2007.

Buchert, Lene. Education in the Development of Tanzania, 1919-90. London: James Currey, 1994.

Burton, Eric. "African Manpower Development During the Global Cold War: The Case of Tanzanian Students in the Two German States." In Africa Research in Austria: Approaches and Perspectives, edited by Andreas Exenberger and Ulrich Pallua, 101-134. Innsbruck: Innsbruck University Press, 2016.

- "Navigating Global Socialism: Tanzanian Students in and Beyond East Germany." Cold War History 19, no. 1 (2019): 63-83.

Coulson, Andrew. Tanzania: A Political Economy. Second Edition. Oxford: Oxford University Press, 2013.

${ }^{67}$ BArch Koblenz, B 213/33099, Füllenbach (GTZ), Besprechungsbericht, Dar es Salaam, 13 July 1982; BMZ, B 213/48210, Gesprächsvermerk über Gespräch mit Vertretern der schweizerischen Direktion für EZA und humanitäre Hilfe (DEH), Bonn, 12 December 1989. 
Crehan, Kate, and Achim von Oppen. "Understandings of 'Development': An Arena of Struggle: The Story of a Development Project in Zambia." Sociologia Ruralis 28, nos. 2-3 (1988): 113-145.

Eckert, Andreas. Herrschen und Verwalten: Afrikanische Bürokraten, staatliche Ordnung und Politik in Tanzania, 1920-1970. München: Oldenbourg, 2007.

Edwards, Sebastian. Toxic Aid: Economic Collapse and Recovery in Tanzania. Oxford: Oxford University Press, 2014.

El-Sayed, Osman L., Juan Lucena, and Gary L. Downey. "Engineering and Engineering Education in Egypt." IEEE Technology and Society 25, no. 2 (2006): 17-24.

Evers, Hans-Dieter. "Globale Macht: Zur Theorie strategischer Gruppen." Working Paper No. 322, Sociology of Development Research Centre Universität Bielefeld, Bielefeld, 1999.

Fitzpatrick, Sheila. "Stalin and the Making of a New Elite." Slavic Review 38, no. 3 (1979): 377-402.

GTZ. Bildung und Wissenschaft in Entwicklungsländern. Die Maßnahmen der staatlichen deutschen Bildungs- und Wissenschaftsförderung. Eschborn: GTZ, 1975.

Hewitt, Tom, and David Wield. "Tanzanian Networks: Networks in Tanzanian Industrialisation." Science and Public Policy 24, no. 6 (1997): 395-404.

Huber, Valeska. "Planning Education and Manpower in the Middle East, 1950s60s." Journal of Contemporary History 52, no. l (2017): 95-117.

Hydén, Göran. Beyond Ujamaa in Tanzania: Underdevelopment and an Uncaptured Peasantry. London: Heinemann, 1980.

Iliffe, John. East African Doctors: A History of the Modern Profession. Cambridge: Cambridge University Press, 1998.

- A Modern History of Tanganyika. Cambridge: Cambridge University Press, 1979.

Itandala, Buluda. "University of Dar es Salaam's Immediate Response to Musoma Resolution." In In Search of Relevance: A History of the University of Dar es Salaam, edited by Isaria N. Kimambo, Bertram B. Mapunda, and Yusufu Q. Lawi, 193-205. Dar es Salaam: Dar es Salaam University Press, 2008.

Ivaska, Andrew M. "Movement Youth in a Global Sixties Hub: The Everyday Lives of Transnational Activists in Postcolonial Dar es Salaam." In Transnational Histories of Youth in the Twentieth Century, edited by Richard I. Jobs and David M. Pomfret, 188-210. Hampshire/New York: Palgrave Macmillan, 2015.

—. "Of Students, 'Nizers,' and a Struggle Over Youth: Tanzania's 1966 National Service Crisis." Africa Today 51, no. 3 (2005): 83-107.

Katsakioris, Constantin. "Creating a Socialist Intelligentsia: Soviet Educational Aid and Its Impact on Africa (1960-1991)." Cabiers d'Études Africaines LVII, no. 2 (2017): 259-287. 
Lal, Priya. African Socialism in Postcolonial Tanzania: Between the Village and the World. Cambridge: Cambridge University Press, 2015.

Miethe, Ingrid. Bildung und soziale Ungleichbeit in der DDR: Möglichkeiten und Grenzen einer gegenprivilegierenden Bildungspolitik. Opladen: Barbara Budrich, 2007.

Njagi, Munene D. “The Upheaval Against Bureaucratic Arrogance.” Maji Maji, no. 3 (1971): 1-6.

Nsekela, Amon S. Socialism and Social Accountability in a Development Nation: Problems in the Transformation of the Tanzanian Economy and Society. Nairobi: Kenya Literature Bureau, 1978.

Nyerere, Julius. The Arusha Declaration: Ten Years After. Dar es Salaam: Government Printer, 1977.

- "The Tanzanian Engineer." Bulletin of Tanzanian Affairs, no. 21 (1985): 12 .

Raikes, P. L. "Ujamaa and Rural Socialism." Review of African Political Economy, no. 3 (1975): 33-52.

Shivji, Issa G. Class Struggles in Tanzania. London: Heinemann, 1978.

United Republic of Tanzania (URT). National Five Year Development Plan 2016/17-2020/21, 30 March 2016. http://www.mof.go.tz/mofdocs/msemaji/Five\%202016_17_2020_21.pdf.

University of Dar es Salaam. A Report on the Activities of the University of Dar es Salaam for the Year 1970-71. Dar es Salaam: University of Dar es Salaam, 1971.

URT. Annual Manpower Report to the President 1969, Dar es Salaam 1970, 18-19.

- Annual Manpower Report to the President 1975. Dar es Salaam: Government Printer, 1976.

Temu, Arnold, and Bonaventure Swai. Historians and Africanist History: A Critique. London: Zed Books, 1981.

Tripp, Aili M. Changing the Rules: The Politics of Liberalization and the Urban Informal Economy in Tanzania. Berkeley: University of California Press, 1997.

Tschannerl, Gerhard. "Rural Water Supply in Tanzania: Is Politics or Technique in Command?" In African Socialism in Practice: The Tanzanian Experience, edited by Andrew Coulson, 86-105. Nottingham: Spokesman, 1979.

Valderrama, Andrés, Juan Camargo, Idelman Mejía, Antonio Mejía, Ernesto Lleras, and Antonio García. "Engineering Education and the Identities of Engineers in Colombia, 1887-1972." Technology and Culture 50, no. 4 (2009): 811-838.

Wield, David, and Carol Barker. "Science, Technology and Development: Part of a Course in Development Studies for First and Second Year Engineering and Medical Students at the University of Dar es Salaam, Tanzania." Social Studies of Science 8 (1978): 385-395. 
Open Access This chapter is licensed under the terms of the Creative Commons Attribution 4.0 International License (http://creativecommons.org/licenses/ by $/ 4.0 /$ ), which permits use, sharing, adaptation, distribution and reproduction in any medium or format, as long as you give appropriate credit to the original author(s) and the source, provide a link to the Creative Commons license and indicate if changes were made.

The images or other third party material in this chapter are included in the chapter's Creative Commons license, unless indicated otherwise in a credit line to the material. If material is not included in the chapter's Creative Commons license and your intended use is not permitted by statutory regulation or exceeds the permitted use, you will need to obtain permission directly from the copyright holder.

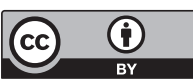

